\title{
Trophic effects on testes in paraplegics
}

\author{
P A Chapelle, ${ }^{1}$ A Roby-Brami, ${ }^{1}$ M Jondet, ${ }^{2}$ T Piechaud, ${ }^{3}$ B Bussel ${ }^{1}$ \\ ${ }^{1}$ Service de Rééducation Neurologique, Hôpital Raymond Poincaré, 92380 Garches; \\ ${ }^{2}$ Laboratoire de la SCALA, 137 Rue de Vaugirard, 75015 Paris; ${ }^{3}$ Clinique St Augustin, \\ 114 Avenue d'Arès, 33000 Bordeaux, France.
}

Testicular biopsies and hormone profiles were obtained from 23 paraplegic patients who had sustained a complete spinal cord section. The hormone profiles were normal, but patients with a spinal lesion including the T10-L2 metameres showed a particular pattern of germinal cell abnormalities. The atrophy is multifactorial, but may well include destruction of the sympathetic innervation of the testis by the lesion.

Keywords: testis; testicular biopsy; spermatogenesis; sympathetic system; paraplegia; trophic effects.

\section{Introduction}

The fertility of male paraplegic patients has received much attention. Ejaculation may be obtained after either pharmacological activation or by electrical stimulation. 1.2 However, fertility depends on the trophic effects on the testes, shown to be altered to varying degrees in paraplegics. ${ }^{3-13}$ The testicular atrophy or alterations of the germinal line have been attributed to a range of factors, including infection, endocrine dysfunction or from an altered general state. However, there appears to be no correlation with the level or the extent of the spinal lesion. We previously found ${ }^{1,14}$ that patients with a spinal lesion destroying the T11-L2 metameres frequently suffered from testicular atrophy (assessed by clinical measurement of the testis). It is therefore important to identify the factors responsible for the testicular damage in order to improve the management of the genitosexual sequelae of paraplegia and the prognosis for procreation.

\section{Methods}

\section{Patients}

A total of 23 male paraplegic patients (25-39 years old) who had consulted for the possibility of recovery of ejaculation took

Correspondence: Dr P A Chapelle, Les Sorbiers, 14 130 St Gatien des Bois, France. part in the study since 1985 . They were examined by the same physician (PAC) and gave their informed consent for the testicular biopsy. All had a total spinal cord section due to indirect trauma at ages 16-29 years. The lesion was considered to be complete on the basis of a clinical examination carried out at least 12 months after the accident (1-19 years).

\section{Neurological examination}

The upper and lower limits of the lesion syndrome were determined from somatic and vegetative reflexes, as previously described. ${ }^{1,15}$ Briefly, the upper limit of the lesion syndrome (ULLS) was the highest metamere displaying a total paralysis, often associated with an upper zone having a partial sensory and/or motor damage. Sensory loss was complete and the patients were incapable of any voluntary movement within and below the ULLS. The lower limit of the lesion syndrome (LLLS) was determined by testing successive spinal reflex activities from segment S5 to the upper segments. The LLLS is the metamere just above the highest metamere which still displays automatic spinal activity (ie corresponding to the highest sublesional afference that can induce a reflex and/or to the highest efference driven by a sublesional stimulation). The spinal injuries of the patients are outlined in Figure 1 and additional clinical data in Table I. 


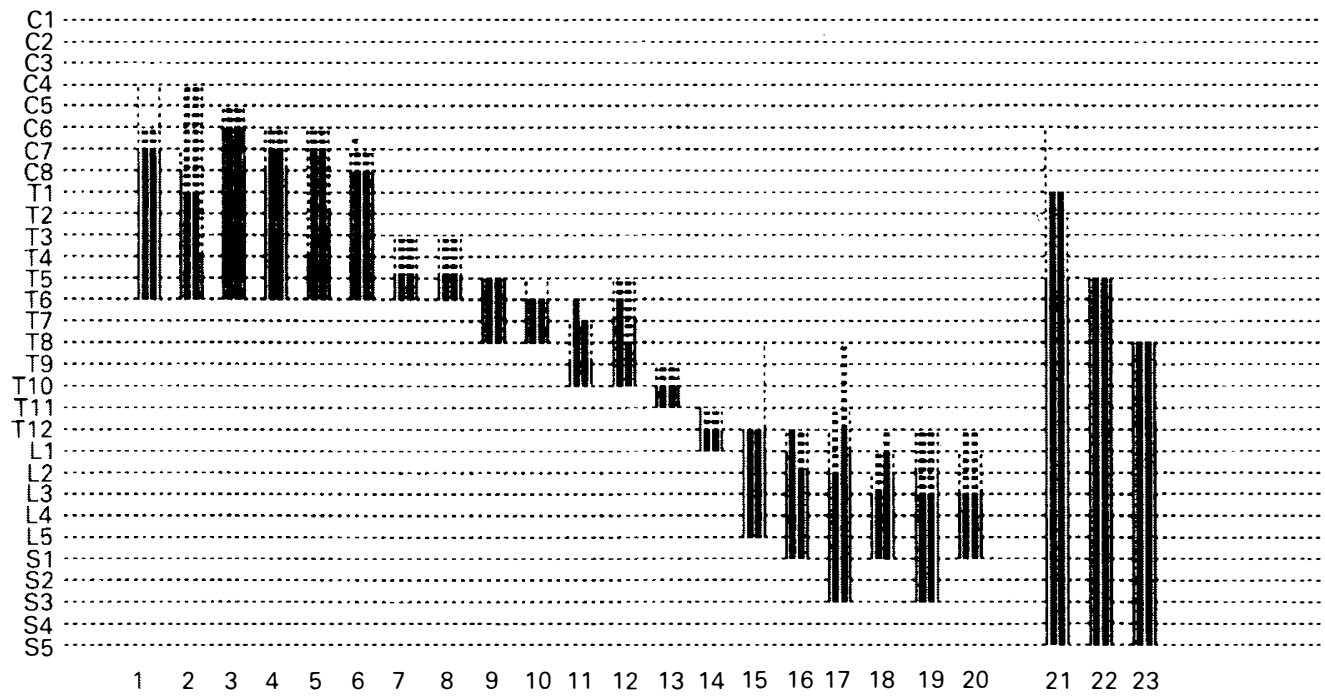

Figure 1 Schema of the spinal lesions. Each set of four lines represents the spinal lesion of one patient across the spinal levels indicated on the ordinate. From left to right: right sensory loss (thin line), right motor loss (thick line), left motor loss (thick line), and left sensory loss (thin line). The dotted parts of the line represent a partial lesion above the complete lesion. Patients 1-20 are classified according to the upper level of their lesion. Patients 21-23 have an extensive spinal lesion.

\section{Investigation procedure}

The same investigation procedure was used for all patients during one week of hospitalisation. At this time, the patients had been free from urinary tract infection for at least 3 months and their bladder management was considered to be equilibrated. A hormonal evaluation was performed on day 1 , followed by the testicular biopsy on day 3 and three physostigmine tests to induce ejaculation on days 2,5 and 7 .

\section{Hormonal evaluation}

The plasma levels of testosterone, oestradiol, prolactin, $\mathrm{FSH}$ and $\mathrm{LH}$ were determined by standard radioimmuno assays.

\section{Testicular biopsy}

Bilateral testicular biopsies were performed without anaesthesia on patients who suffered from cervical or high thoracic lesion. Premedication and local anaesthesia were used for those patients with any residual testicular sensitivity.

The scrotal skin was incised, and the tunica albuginea was exposed. A $5 \mathrm{~mm}$ incision was made in the tunica and the testicular tissue was separated from the tunica by lateral undercuts. External pressure on the testis was avoided: the underlying seminiferous tubules protruded above the tunica due to internal pressure. This protruded tissue was cut off with curved scissors and was immediately fixed in Bouin's fixative. The fixed tissue was embedded in paraffin and four micrometer sections were cut and stained with Masson's trichrome stain (Haematoxylin, Fuchsin, Aniline blue).

The seminiferous epithelium was quantified by one of us (MJ) who was not informed of the clinical data at the time of the examination. Randomly chosen cross sections of the tubules were used for quantification of the seminiferous epithelium after exclusion of areas with artefacts. A total of 10 tubular cross sections were counted on each testis. The diameter of the tubule and the thickness of the tunica propria were measured in micrometers. The cells of the seminiferous epithelium were classified according to the criteria of Heller and Clermont. ${ }^{16}$ Spermatogonia, spermatocytes, 
Table I The main clinical details of the patients' spinal injuries

\begin{tabular}{|c|c|c|c|c|c|c|c|}
\hline \multirow[t]{2}{*}{ Patient } & \multirow{2}{*}{$\begin{array}{c}\text { Age at } \\
\text { injury } \\
\text { (yrs) }\end{array}$} & \multirow{2}{*}{$\begin{array}{l}\text { Time from } \\
\text { injury } \\
\text { (yrs) }\end{array}$} & \multicolumn{4}{|c|}{ Sensitivity } & \multirow[t]{2}{*}{ LLLS } \\
\hline & & & $\mathrm{L}$ & $\mathrm{R}$ & $\mathrm{L}$ & $\mathrm{R}$ & \\
\hline 1 & 18 & 19 & C7 & C7 & C7 & C7 & T6 \\
\hline 2 & 22 & 5 & C8 & $\mathrm{T} 4$ & $\mathrm{~T} 1$ & $\mathrm{~T} 1$ & T6 \\
\hline 3 & 18 & 15 & C6 & C6 & C6 & C6 & C6 \\
\hline 4 & 17 & 16 & $\mathrm{C} 8$ & $\mathrm{C} 8$ & $\mathrm{C} 7$ & $\mathrm{C} 7$ & T6 \\
\hline 5 & 18 & 13 & $\mathrm{~T} 4$ & $\mathrm{~T} 2$ & $\mathrm{C} 7$ & C7 & T6 \\
\hline 6 & 27 & 1 & C8 & $\mathrm{C} 8$ & $\mathrm{C} 8$ & C8 & T6 \\
\hline 7 & 19 & 9 & T5 & T5 & T5 & T5 & T6 \\
\hline 8 & 26 & 10 & T5 & T5 & T5 & T5 & T6 \\
\hline 9 & 16 & 8 & T5 & T5 & T5 & T5 & T8 \\
\hline 10 & 16 & 11 & T6 & T6 & T6 & T6 & T8 \\
\hline 11 & 18 & 12 & T9 & T9 & T6 & $\mathrm{T} 7$ & T0 \\
\hline 12 & 18 & 13 & T9 & T9 & T6 & $\mathrm{T} 8$ & $\mathrm{~T} 10$ \\
\hline 13 & 21 & 13 & $\mathrm{~T} 10$ & $\mathrm{~T} 10$ & $\mathrm{~T} 10$ & $\mathrm{~T} 10$ & $\mathrm{~T} 10$ \\
\hline 14 & 22 & 3 & $\mathrm{~T} 11$ & $\mathrm{~T} 12$ & $\mathrm{~T} 12$ & $\mathrm{~T} 12$ & L1 \\
\hline 15 & 26 & 2 & $\mathrm{~T} 12$ & $\mathrm{~T} 12$ & $\mathrm{~T} 12$ & T12 & L5 \\
\hline 16 & 18 & 9 & L3 & L3 & L3 & L3 & $\mathrm{S} 1$ \\
\hline 17 & 27 & 11 & L2 & L1 & L2 & T12 & $\mathrm{S} 1$ \\
\hline 18 & 29 & 7 & L3 & L2 & L3 & T12 & $\mathrm{S} 1$ \\
\hline 19 & 22 & 2 & L2 & L2 & L3 & L3 & S5 \\
\hline 20 & 26 & 2 & L3 & L3 & L3 & L3 & $\mathrm{S} 1$ \\
\hline 21 & 17 & 22 & T5 & T5 & $\mathrm{T} 1$ & $\mathrm{~T} 1$ & S5 \\
\hline 22 & 23 & 1 & T5 & T5 & T5 & T5 & S5 \\
\hline 23 & 25 & 1 & T8 & $\mathrm{T} 8$ & $\mathrm{~T} 8$ & $\mathrm{~T} 8$ & S5 \\
\hline
\end{tabular}

ULLS = upper limit of the lesion syndrome.

LLLS $=$ lower limit of the lesion syndrome.

early and late spermatids were counted independently in each cross tubular section. All Sertoli cells with visible nucleoli were also counted. The total number of each type of germ cell was divided by the total number of Sertoli cells in the same tubular cross section to give the Sertoli cell ratio. All values were referred to the normal values for testicular epithelium listed by Skakkebaek and Heller. ${ }^{17}$ Leydig cells were assessed using the Leydig cell-Sertoli cell ratio, normality was defined for ratio between 0.1 and 0.5 , hypoplasia for ratio under 0.1 , slight hyperplasia for ratio over 0.5 and severe hyperplasia for ratio over 1 . The vascular supply was assessed subjectively.

\section{Physostigmine tests}

Patients with a spinal cord section may ejaculate after pharmacological activation by physostigmine, as has been fully described elsewhere. ${ }^{1,14}$ Each test consisted of a subcutaneous injection of physostigmine (1-2 mg plus $40-80 \mathrm{mg}$ N-butylhyoscine), followed by masturbation. The semen was examined and the presence of spermatozoa verified.

\section{Results}

Classification of the spinal lesions

The patients were classified as a function of the level of their spinal lesion, plus any partially and/or asymmetrically injured levels. The left part of Figure 1 shows the lesions of the patients. The patients with the highest lesion are shown in the leftmost part of the figure and 3 patients with extensive lesions of the spinal cord (ie extending from the thoracic to the sacral levels) are shown separately on the right part of the figure. 


\section{Testicular biopsy}

The diameter of the seminiferous tubules was slightly but not significantly reduced in the patients (mean $174 \mu \mathrm{m}$, range 113$228 \mu \mathrm{m})$ compared to subjects without neurological lesions (mean $197 \mu \mathrm{m}$, range $167-227 \mu \mathrm{m})$. The tunica propria of the patients was thicker $(6.95 \mu \mathrm{m}$, range $3-$ $10.4 \mu \mathrm{m})$ than in normal subjects $(1-2 \mu \mathrm{m})$. The numbers of Sertoli cells per tubule section of patients (13.8, range 9.5-18.3) and control subjects (12, range 7-18.9) were the same. These values did not appear to vary with the age of the patients, the time elapsed since their spinal cord injury, or the level of their lesion.

The condition of the Leydig cells and the vascular supply in the testicular biopsies of patients is shown in Table II. The Leydig cells appeared to be normal in 13 cases, hypoplastic in 5 cases and hyperplastic in 5 cases. The alterations were symmetrical, except in 4 cases. There was no apparent correlation between the condition of the Leydig cells and the spinal lesion. In some patients there was moderate arteriolar sclerosis $(\mathrm{Sc})$ or capillary congestion $(\mathrm{Co})$, which was mostly symmetrical. The vascular supply showed both arteriolar sclerosis and capillary congestion of both testes in one patient, and of the left testis in another (patient 16). Although congestion is probably due to the operative procedure, the present cases could be related to a vasomotor phenomenon since anaesthesia and testicular pressure were avoided during the biopsy.

Figure 2 shows the Sertoli cell ratios of the germinal cells for all the patients, plus the range of values for normal subjects (left part of Figure 2). There was no evident variation in the number of germinal cells as a function of the patient's age or the time elapsed since their spinal cord injury. The quantitative analysis of the germinal cells for each patient (Figure 2) using the same

Table II The main clinical details of the urogenital history of the patients and qualitative results of the testiculr biopsy

\begin{tabular}{|c|c|c|c|c|}
\hline Patient & History & Ejaculation & Leydig cells & Vascular supply \\
\hline 1 & & Yes & Hyper & Sc \\
\hline 2 & & Yes & $\mathrm{N}$ & Co \\
\hline 3 & & Yes & $\mathrm{N}$ & Co \\
\hline 4 & & Yes & $\mathrm{N}$ & $\mathrm{N}$ \\
\hline 5 & Ishaemia & Yes & Нуро & $\mathrm{Sc}+\mathrm{Co}$ \\
\hline 6 & & Yes & L Hyper & L Co \\
\hline 7 & & Yes & $\mathrm{N}$ & $\mathrm{Sc}$ \\
\hline 8 & & Yes & $\mathrm{N}$ & Co \\
\hline 9 & R Orch & Yes & $\mathrm{N}$ & $\mathrm{Sc}$ \\
\hline 10 & & Yes & $\mathrm{N}$ & L Sc \\
\hline 11 & & Yes & Hyper & $\mathrm{Sc}$ \\
\hline 12 & & No & Нypo & Sc \\
\hline 13 & R Orch & Yes & $\mathrm{N}$ & $\mathrm{N}$ \\
\hline 14 & & No & L Hyper & Sc \\
\hline 15 & L Orch & No & Hyper & Sc \\
\hline 16 & R Orch & No & $\mathrm{N}$ & $\mathrm{Sc}+\mathrm{L} \mathrm{Co}$ \\
\hline 17 & & No & L Hypo & Sc \\
\hline 18 & & No & $\mathrm{N}$ & $\mathrm{N}$ \\
\hline 19 & & No & $\mathrm{N}$ & Sc \\
\hline 20 & & No & L Нypo & Sc \\
\hline 21 & & No & $\mathrm{N}$ & $\mathbf{N}$ \\
\hline 22 & & No & $\mathrm{N}$ & $\mathrm{N}$ \\
\hline 23 & & No & Нуро & $\mathrm{N}$ \\
\hline
\end{tabular}

$\mathrm{N}=$ normal $;$ Orch $=$ epididymo-orchitis $; \mathrm{Sc}=$ moderate arteriolar sclerosis; $\mathrm{Co}=$ capillary congestion. 


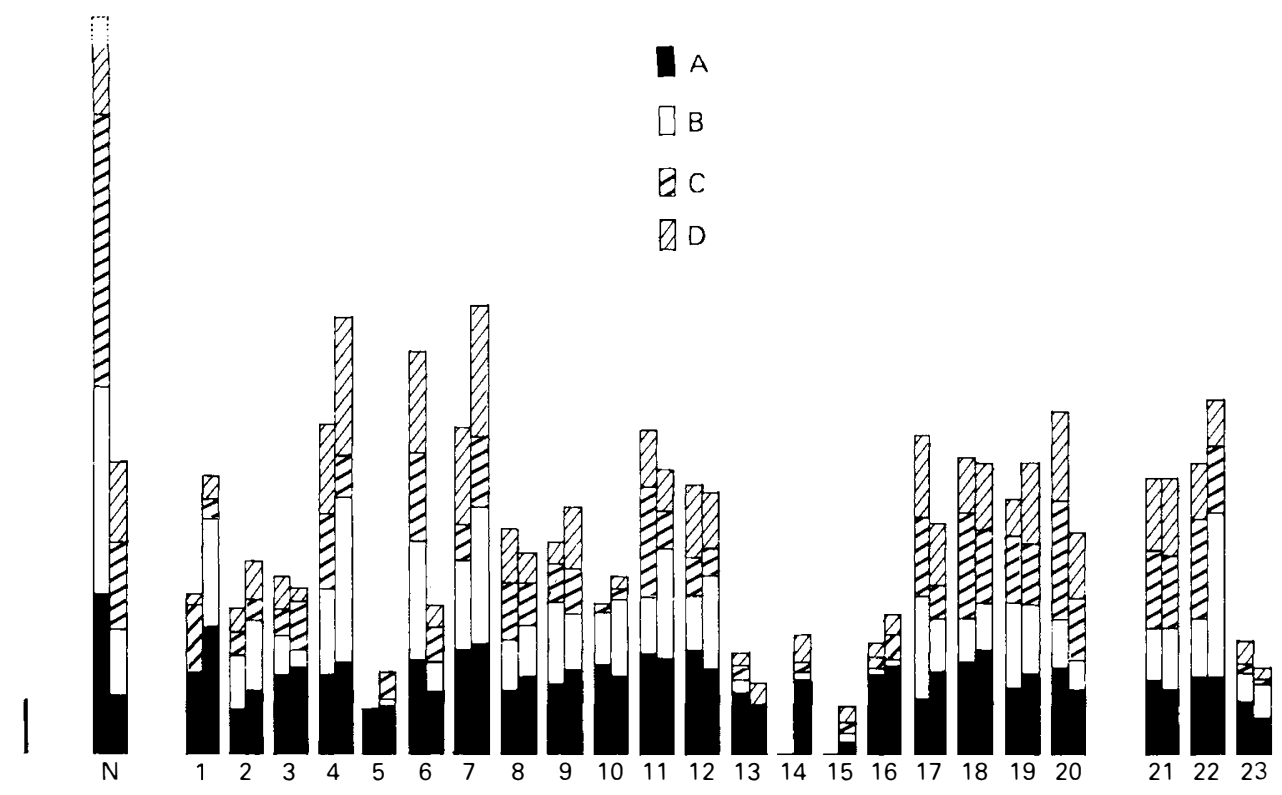

Figure 2 Testicular biopsy data. The cumulated histograms represent the Sertoli cell ratio (number of germ cells/number of Sertoli cells) of the germ cells (A: spermatogonia, B: spermatocytes, C: early spermatids, D: late spermatids). The calibration bar represent a ratio of 1 . The paraplegic patients are classified as in Figure 1. For each patient, the two bars indicate the results of the biopsies of the right and left testes. The two cumulated bars on the left of the figure represent the upper and lower values for normal subjects $(\mathrm{N})$.

patient classification as in Figure 1 was used to compare the spinal lesion and the results of the testicular biopsy.

In most patients, the number of germinal cells was close to the lowest values for the normal subjects. The biopsy data were inconsistently symmetrical. The number of spermatogonia was generally within the limits of control values, except in some patients in which it was frankly reduced or zero in one testis. Since the spermatogonia are the start of the germinal line, the later stages of spermatogenesis were severely disrupted in the testis lacking spermatogonia. Other patients frequently showed a maturational arrest at the spermatocyte stage (ie the number of spermatocytes was within the normal range but the number of spermatids was reduced). The number of germinal cells varied with the spinal lesion. Except in patient 5, the spinal lesions of the patients with a clear decrease in germinal cells included the low thoracic-high lumbar segments (patients 13-16 and patient 23). Accordingly, patient 17 had an asymmetrical testicular impairment corresponding to an asymmetrical neurological lesion. Four patients had a history of epididymoorchitis and in 3 of them the spinal cord lesion involved the low thoracic-high lumbar segments (Table II). Patient 5 was exceptional since anamnesis and clinical examination indicated that his testes had been subjected to compression by strong adductor spasticity, probably inducing a prolonged rise in the deep scrotal temperature $^{18}$ and testicular ischaemia.

\section{Hormonal evaluation}

The mean hormone concentrations were not different from normal values (Table III). The hormone concentrations did not vary significantly with age, the time since the spinal injury, or the level of the spinal injury. 
Table III Hormone concentrations

\begin{tabular}{lcc}
\hline & Mean \pm standard deviation in patients & Normal values \\
\hline Testosterone & $5.2 \pm 1.8 \mathrm{ng} / \mathrm{ml}$ & $2-8 \mathrm{ng} / \mathrm{ml}$ \\
Oestradiol & $26.7 \pm 15 \mathrm{pg} / \mathrm{ml}$ & $8-45 \mathrm{pg} / \mathrm{ml}$ \\
Prolactin & $7.38 \pm 2.9 \mathrm{ng} / \mathrm{ml}$ & below $15 \mathrm{ng} / \mathrm{ml}$ \\
FSH & $5.43 \pm 4.5 \mathrm{mU} / \mathrm{ml}$ & $1.5-12 \mathrm{mU} / \mathrm{ml}$ \\
LH & $5.48 \pm 2.7 \mathrm{mU} / \mathrm{ml}$ & $2.1-9.8 \mathrm{mU} / \mathrm{ml}$ \\
\hline
\end{tabular}

\section{Ejaculation}

Ejaculation occurred after pharmacological activation by physostigmine in 12 out of 23 patients, and spermatozoa were present in the ejaculate (Table II). All of them had a high spinal lesion which spared the lower thoracic metameres. Patient 13 had ejaculated during a physostigmine test performed 3 years before the testicular biopsy; at that time the ejaculate $(0.6 \mathrm{ml})$ contained 20000 spermatozoa $/ \mathrm{mm} 3,5 \%$ of which were moving. At the time of the testicular biopsy, performed 1 month after surgical resection of the right ischium for osteitis he could not ejaculate.

\section{Discussion}

\section{Ejaculation}

We have previously shown ${ }^{1,14}$ that the integrity of the low thoracic-high lumbar metameres is essential for ejaculation. Patients with a high spinal lesion whose lower limit is above D11 or with a low spinal lesion whose upper limit is below L2 can usually ejaculate during a physostigmine test, but not if the D11-L2 metameres are lesioned. The present study confirms these results, but some patients (18-20) with an upper lesion level below L2 did not ejaculate.

\section{Trophic effects on the testes}

The testicular biopsies of some patients indicated selective alterations of germinal cells, such as tubular atrophy or maturational arrest without alterations of Leydig cells, which are consistent with published results. ${ }^{3,5-13}$ The selective alteration of the Sertoli cell ratio of spermatids is consistent with the quantitative results of Hirsh et al..$^{5}$ However, both testes were biopsied in the present study, thus providing greater pre- cision since some patients showed asymmetrical lesions.

Cachexia or severe medical complications which can induce testicular atrophy can be ruled out in the present population of paraplegic patients, as in the more recent studies. ${ }^{5,10}$ General endocrinological changes can also be dismissed, since the hormone profiles of our patients were normal, ${ }^{19,20}$ although small endocrinological changes have been found in paraplegics by some workers. ${ }^{9,10}$ Urogenital infection is probably involved in the testicular damage of several patients, as frequently reported in other studies. ${ }^{10,11}$ Most of our patients had had paraplegia for a long time with a history of urogenital infection. However, the short term effect of urogenital infection on spermatogenesis was ruled out in our study since the patients were free from infection for at least 3 months at the time of the biopsy (which is the duration of maturation for the germinal cells).

Previous studies showed no relationship between testicular atrophy and the level of the lesion. The precise analysis of the upper and lower limit of the lesion shed some light on the physiopathological mechanisms involved in germinal epithelium alterations. As proposed in a previous study based on clinical measurements of testicular volume, ${ }^{1}$ atrophy seems to be linked to lesions at the low thoracic-high lumbar levels. However, testicular damage is clearly multifactorial. The neural lesion may disrupt the testis blood supply or cause an elevation of the deep scrotal temperature. ${ }^{18}$ Epididymoorchitis and urogenital infections may also contribute to the testicular atrophy since some of our patients with a lesion of the lower thoracic-upper lumbar metameres had history of epididymo-orchitis. Recent surgery may have complicated the response 
of patient 13. Long term compression of the testis induced atrophy, independent of the level of the lesion in patient 5 .

\section{Pathophysiological hypothesis}

At the level of the spinal injury the innervated metameres are deprived of upper control and of any somatic or vegetative tonic activity. In particular, there is no vasomotor activity in the somatic ${ }^{15}$ and visceral territories depending on the injured metameres. By contrast, the metameres below the level of the lesion are deprived of upper level control but retain strong automatic activity. The testes receive visceral sympathetic innervation from metameres D10-L2 and innervation from sacral segments. ${ }^{21}$ We propose that the neural trophic influence on the testes is as follow:

1 If the lesion is high, (ie if the LLLS is above T10, patients 1-12) the orthoand parasympathetic testicular innervations are undamaged and 'automatic'. The spermatogonia are mostly normal, but there is a progressive loss of the more mature cells, mainly spermatids.

2 If the lesion involves only a few segments at the T10-L2 level (patients 13-17), the testicular sympathetic innervation is interrupted or damaged, but parasympathetic fibres are probably spared. This lesion seems to have two consequences which produce poor trophic stimulation of testes: selective damage to the maturational phase between spermatogonia and spermatocytes and/or a greater risk of genital infection. This view is supported by the findings of Coujard, ${ }^{22}$ who demonstrated that the sympathetic ganglion cell was a target for circulating hormones and that a lesion of the sympathetic innervation induced testicular atrophy.

3 If the lesion is low (ie the ULLS below
L2, patients 18-20), most of the sympathetic fibres can reach the testis under upper control, but the parasympathetic fibres cannot. Spermatogenesis is not strongly affected.

4 If the lesion is extended from an upper level above T10 to sacral levels (patients 21-23), both sympathetic and the parasympathetic testicular innervations are destroyed. The germinal cells are not frankly altered (except in patient 23). The deleterious effect of the sympathetic lesion seems to be decreased by a parasympathetic lesion, as if both types of visceral innervation had concurrent effects on the trophic stimulation of testes.

Thus paraplegia appears to have a global effect on the maturation of the germinal cells (population 1), which is more severe if the lesion includes the T10-L2 segments (population 2). However, a concurrent lesion of the sacral zone (populations 3,4 ) seems to have a protective effect.

\section{Conclusion}

Testicular biopsies from patients with spinal cord lesions provide information on the changes in spermatogenesis. They may thus facilitate the management of infertility in paraplegic patients, since the pharmacological activation of ejaculation is not indicated if spermatogenesis is inadequate.

The prognosis for procreation is clearly worsened if the lesion includes the lower thoraco-upper lumbar segments, but the mechanism appears to be complex. Improved clinical examination techniques are required in order to obtain more precise knowledge on the lesions of the autonomic nervous system.

Mechanical compression of the testis by spastic adducted thighs can lead to testicular damage, and should therefore be avoided by appropriate positioning of the legs.

\section{References}

1 Chapelle PA, Roby-Brami A, Yakovleff A, Bussel B (1988) Neurological correlations of ejaculation and testicular size in man with a complete spinal cord section. J Neurol Neurosurg Psychiatry 51: 197-202.

2 Brindley GS (1981) Electroejaculation: Its technique, neurological implications and uses. J Neurol Neurosurg Psychiatry 44: 4-18. 
3 Bors E, Engle ET, Rosenquist RC, Hollinger VH (1950) Fertility in paraplegic males. A preliminary report of endocrine studies. J Clin Endocrinol 10: 381-398.

4 Claus-Walker J, Scurry M, Carter M, Campos RJ (1977) Steady-state hormonal secretion in traumatic quadriplegia. J Clin Metab 44: 530-535.

5 Hirsch IH, McCue P, Allen J, Lee J, Staas WE (1991) Quantitative testicular biopsy in spinal cord injured men: comparison to fertile controls. J Urol 146: 337-341.

6 Horne HW, Paull DP, Munro D (1948) Fertility studies in the human male with traumatic injuries of the spinal cord and cauda equina. New J Engl Med 239: 959-961.

7 Klein M, Fontaine R, Stoll G, Dany A, Frank P (1952) Modifications histologiques des testicules chez les paraplégiques. Revue Neurologique 86: 501-503.

8 Leriche A, Berard E, Vauzelle JL, Minaire P, Girard R, Archimbaud JP et al (1977) Paraplegia 15: 274-279.

9 Morley JE, Distiller LA, Lissoos I, Lipshitz R, Kay G, Searle DL et al (1979) Testicular function in patients with spinal cord damage. Horm Metab Res 11: 679-682.

10 Perkash I, Martin DE, Warner H, Blank MS, Collins DC (1985) Reproductive biology of paraplegics: results of semen collection, testicular biopsy and serum hormone evaluation. J Urol 134: 284-288.

11 Stemmermann GN, Weiss L, Auerbach O, Friedman M (1950) A study of the germinal epithelium in male paraplegics. Am J Clin Pathol 20: 24-34.

12 Talbot HS (1955) The sexual function in paraplegia. J Urol 73: 91-100.

13 Tsuji I, Nakajima F, Morimorito J, Nounaka Y (1961) The sexual function in patients with spinal cord injury. Unrol Int 12: 270-280.

14 Chapelle PA, Blancart F, Puech AJ, Held JP (1983) Treatment of an ejaculation in the total paraplegic by subcutaneous injection of physostigmine. Paraplegia 21: 30-36.

15 Chapelle PA, Leroy F, Roby A, Bussel B (1984) Estimation topographique de la limite inférieure du syndrome lésionnel chez l'homme paraplégique complet. Ann Réadapt Med Phys 26: 369-377.

16 Heller CG, Clermont Y (1964) Kinetics of the germinal epithelium in man. Rec Progr Horm Res 20: $545-571$.

17 Skakkebaek NE, Heller CG (1973) Quantification of human seminiferous epithelium. I-Histological studies in twenty-one fertile men with normal chromosome complements. J Reprod Fertil 32: 379-389.

18 Brindley GS (1982) Deep scrotal temperature and the effect on it of clothing, air temperature, activity posture and paraplegia. Brit J Urol 54: 49.

19 Mitzutani S, Sonoda T, Matsumoto K, Iwasa K (1972) Plasma testosterone concentration in paraplegic men. J Endocrinol 54: 363-364.

20 Young RJ, Strachan RK, Seth J, Nicol K, Frier BM, Corrall RJM (1982) Is testicular endocrine function abnormal in young men with spinal cord injuries? Clin Endocrinol 17: 303-306.

21 Johnson RH, Spalding JMK (1974) Disorders of the Autonomic Nervous System. Blackwell Scientific Publications, Oxford.

22 Coujard R (1958) Le facteur nerveux périphérique. Ses incidents sur la spermatogenèse. In: Bayle $H$, Gouygou C, Guillon G, editors. La Fonction Spermatogénétique du Testicule Humain. Masson, Paris: 91-105. 